\title{
KOALISI PARTAI POLITIK DAN IMPLIKASINYA TERHADAP SISTEM PRESIDENSIAL MULTIPARTAI DI INDONESIA
}

\author{
Moch. Marsa Taufiqurrohman, Fakultas Hukum Universitas Jember, \\ E-mail: mochmarsa_t@yahoo.co.id
}

doi: https://doi.org/10.24843/KS.2020.v09.i01.p12

\begin{abstract}
ABSTRAK
Artikel ini berupaya meninjau kembali praktik koalisi partai politik di tengah sistem presidensial pasca reformasi, dan menilai sejauh mana dampaknya terhadap kestabilan pemerintahan. Pasca reformasi 1998, sejumlah besar partai politik telah didirikan, menunjukkan bahwa munculnya fragmentasi politik adalah sesuatu yang tidak terhindarkan. Alih-alih melaksanakan pemerintahan secara sehat, partai politik membentuk koalisi untuk memperkuat kedudukan mereka di parlemen. Implikasi penerapan multi partai dalam sistem presidensial ini seringkali menimbulkan deadlock antara eksekutif dan legislatif. Sistem presidensial yang dikombinasikan dengan sistem multi partai dapat menjadi sistem yang stabil dan efektif dengan cara penyederhanaan partai politik, desain pelembagaan koalisi, dan pengaturan pelembagaan oposisi. Namun di sisi lain koalisi juga menjadi sangat berpengaruh pada stabilitas pemerintahan. Dengan menggunakan metode penelitian yuridis normatif, artikel ini bertujuan untuk meneliti politik hukum terkait praktik koalisi partai politik di Indonesia dan mengetahui upaya-upaya dalam praktik ketatanegaraan yang dapat merealisasikan stabilitas sistem pemerintahan presidensial pada koalisi di multi partai. Artikel ini menemukan kesimpulan bahwa model pemilihan legislatif dan eksekutif yang dipilih langsung oleh rakyat justru menjadi penyebab disharmonisasi antara legislatif dan eksekutif yang mengarah kepada terjadinya kebuntuan antar kedua lembaga tersebut. Lebih-lebih apabila yang menguasai lembaga ekesekutif dan lembaga legislatif adalah dari latar belakang partai politik yang berbeda. Akibatnya, praktik koalisi seperti ini cenderung mengakibatkan lebih banyak masalah, sehingga penerapan sistem ini memiliki dampak signifikan terhadap demokrasi yang didefinisikan dan dinegosiasikan.
\end{abstract}

Kata Kunci: Implikasi Koalisi, Partai Politik, Sistem Presidensial.

\begin{abstract}
This article attempts to review the practice of coalitions of political parties in the post-reform presidential system and assess the extent of their impact on the stability of the government. Post-1998 reform, a large number of political parties have been established, suggesting that the emergence of political fragmentation is inevitable. Instead of implementing a healthy government, political parties formed coalitions to strengthen their positions in parliament. The implication of implementing multi-party in the presidential system often creates deadlocks between the executive and the legislature. A presidential system combined with a multi-party system can become a stable and effective system by simplifying political parties, designing institutionalized coalitions, and organizing opposition institutions. But on the other hand, the coalition has also greatly influenced the stability of the government. By using normative juridical research methods, this article aims to examine legal politics related to the practice of political party coalitions in Indonesia and to find out the efforts in state administration practices that can realize the stability of the presidential system of government in multi-party coalitions. This article finds the conclusion that the legislative and executive election models directly elected by the people are the cause of disharmony between the legislature and the executive which leads to a deadlock between the two institutions. This is even more so if those who control the executive and legislative bodies are from
\end{abstract}


different political party backgrounds. As a result, coalition practices like this are likely to cause more problems, so the adoption of these systems has a significant impact on defined and negotiated democracy.

Keywords: Implications of Coalitions, Political Parties, Presidential System.

\section{Pendahuluan}

\subsection{Latar Belakang Masalah}

Dalam sistem pemerintahan presidensial dalam suatu negara heterogen dengan multipartai sangat tidak efektif, karena polarisasi masyarakat yang dimanifestasikan dalam parlemen, menjadikan sebuah parlemen yang bersifat cair, mudah berubah dan sangat fleksibel, hal ini sangat berlawanan dengan hakekat kekuasaan eksekutif pemerintahan presidensial yang bersifat rigid. ${ }^{1}$ Rigiditas eksekutif yang tercermin dengan masa jabatan fixed term dan Presiden yang tidak dapat dijatuhkan oleh legislatif, akan membuat frustasi rakyat yang harus menunggu sampai masa jabatan Presiden berakhir baru kemudian memilih kembali Presiden dalam pemilihan umum. ${ }^{2}$

Dalam pemerintahan presidensial pemilihan umum ada dua yakni pemilihan anggota legislatif dan pemilihan Presiden dan karena Presiden memegang kekuasaan untuk menjalankan pemerintahan, maka pemilihan umum Presiden menjadi sangat penting yang menentukan arah kebijakan Negara. Dalam sistem ini maka program yang ditawarkan oleh calon presiden merupakan program yang bersifat keeksekutifan. ${ }^{3}$ Partai politik dalam pemilihan umum di pemerintahan presidensial lebih bersifat sebagai penopang atau pendukung bagi program calon presiden yang didukungnya. Dengan demikian partai politik cenderung sebagai kendaraan politik untuk memperoleh kedudukan atau jabatan politik, karena popularitas calon presiden menjadi faktor terpenting dalam model pemilihan umum ini dibandingkan dengan program partai politik. ${ }^{4}$

Kelemahan yang banyak dijumpai dalam partai politik di Indonesia yakni kurangnya kemampuan untuk membangun kapasitas dan integritas kelembagaan. Paling tidak ada empat hal yang menyebabkan hal tersebut, yaitu:

1. Proses rekrutmen anggota partai maupun pimpinan partai, khususnya di tingkat bawah tidak diatur secara utuh dan sistematis. Juga tidak ada aturan yang komprehensif yang mengatur seorang anggota baru untuk bisa duduk di dalam jajaran fungsionaris dan struktur partai:

2. Mekanisme komunikasi antara kader partai dan anggota parlemen dengan konstituennya atau rakyat untuk memahami aspirasi yang berkembang di masyarakatnya tidak cukup diatur dan tidak dilakukan; 5

1 Asep Nurjaman, "The End of Political Party in Indonesia: The Case of Weakening Voter's Loyality in the Local Level, Malang," The Social Sciences 12, no. 2 (2017): 5.

2 Sungdeuk Lee dan Burhan Djabir Magenda, "Comparative Case Study on Institutionalization of Ruling Parties Under Military Authoritarianism: Democratic Republican Party Under Park Chung-Hee Regime in South Korea (1961-1979) and GOLKAR Under Suharto Regime in Indonesia (1966-1998)," Journal of Social and Political Sciences 2, no. 4 (2019): 11.

3 Amalinda Savirani, "The Political Middle Class in Post-Soeharto Era Indonesia," Continuity and Change after Indonesia's Reforms: Contributions to an Ongoing Assessment, 2019, 24.

4 Andi Naharuddin, "ELECTIONS IN INDONESIA AFTER THE FALL OF SOEHARTO," 2016, 15.

5 Auradian Marta dkk., "The Crisis of Democratic Governance in Contemporary Indonesia," Jurnal Ilmiah Peuradeun 8, no. 1 (2020): 8. 
Proses pengkaderan partai secara berjenjang untuk memahami ideologi dan program strategis partai serta peningkatan kemampuan kepemimpinan dilakukan tidak serius dan konsisten. ${ }^{6}$

Menurut Matthew Shugart dan Scott Mainwaring, perbedaan utama antara sistem presidensial dengan parlementer ada dua hal yakni:7 Pertama, dalam sistem presidensial presiden dipilih oleh rakyat sedangkan dalam sistem parlementer kepala pemerintahan dipilih oleh parlemen. Kedua, Presiden dan lembaga perwakilan dalam sistem presidensial mempunyai masa jabatan yang tetap (fixed term) sedangkan dalam sistem parlementer masa jabatan kepala pemerintahan dan parlemen sangat tergantung pada kepercayaan parlemen. Bisa saja parlemen mengajukan mosi tidak percaya kepada kepala pemerintahan sehingga kepala pemerintahan tersebut meletakkan jabatannya di tengah masa jabatannya atau juga kepala pemerintahan membubarkan parlemen dan mempercepat pemilihan umum untuk mengisi parlemen yang dibubarkan. ${ }^{8}$

Merujuk pada teori kedaulatan rakyat dan teori demokrasi modern dimana rakyat yang menentukan jalannya negara melalui mekanisme pemilihan umum. Maka pemilihan presiden (dan wakil presiden) secara langsung merupakan bentuk legitimasi rakyat untuk dalam menjalankan kedaulatannya terhadap negara. ${ }^{9}$

Pemilihan Presiden secara langsung oleh rakyat ini bertujuan untuk memberikan legitimasi yang kuat sama seperti halnya legislatif yang anggotanya juga dipilih oleh rakyat. Dengan demikian kedudukan antara presiden dengan lembaga perwakilan sama- sama seimbang. ${ }^{10}$ Pemilihan presiden oleh rakyat ini juga bermakna filosofis dimana dalam sistem presidensial, presiden merupakan pemegang kekuasaan eksekutif tertinggi sekaligus sebagai kepala negara, maka presiden memiliki kekuasaan yang besar dan dengan kekuasaan yang besar ini dibutuhkan seorang pemimpin yang dapat diterima oleh mayoritas masyarakat. ${ }^{11}$

Berbeda dengan sistem presidensial, dalam sistem parlementer pemilihan umum hanya dilakukan untuk memilih anggota lembaga perwakilan, yakni parlemen. Dalam sistem ini kedaulatan sepenuhnya dijalankan oleh parlemen. Dalam sistem ini terdapat pemisahan yang tegas antara kepala pemerintahan dengan kepala negara.

Dalam sistem pemerintahan presidensial dengan multipartai dimana tidak ada partai politik yang memperoleh suara mayoritas dalam pemilihan umum, maka dalam pembentukan kabinet Presiden harus mempertimbangkan keikutsertaan partai politik lain dalam suatu koalisi. ${ }^{12}$ Akan tetapi koalisi ini tidak bersifat permanen karena

6 Diego Fossati, "Electoral reform and partisan dealignment in Indonesia," International Political Science Review 41, no. 3 (2020): 11.

7 Blane D. Lewis, "Endogenous district magnitude and political party fragmentation in subnational Indonesia: A research note," Electoral Studies 55 (2018): 16.

8 Moh Ilham A. Hamudy dan M. Saidi Rifki, "Strengthening the Multi-Party Presidential Government in Indonesia," Politik Indonesia: Indonesian Political Science Review 4, no. 2 (2019): 18.

9 Eve Warburton dan Edward Aspinall, "Explaining Indonesia's Democratic Regression," Contemporary Southeast Asia 41, no. 2 (2019): 19.

10 Sunny Ummul Firdaus, "Relevansi parliamentary threshold terhadap pelaksanaan pemilu yang demokratis," Jurnal Konstitusi 8, no. 2 (2016): 24.

11 Nico Handani Siahaan, "Formula Penyederhanaan Jumlah Partai Politik Di Parlemen Pada Pemilihan Umum Indonesia," Politika: Jurnal Ilmu Politik 7, no. 1 (2016): 20.

12 Firman Freaddy Busroh, "Reformulasi Penerapan Electoral Threshold dalam Sistem Kepartaian di Indonesia," Jamal Lex Librum 3, no. 2 (2017): 20. 
menteri bertanggungjawab langsung kepada Presiden dan tidak kepada parlemen. Oleh karena itu partai politik dalam parlemen tidak mempunyai kewajiban untuk mendukung pemerintah, meskipun memiliki wakil di kabinet.

Dua pemilihan umum dalam sistem presidensial merupakan pemilihan umum yang terpisah dan tidak berkaitan sama sekali, sehingga dalam sistem ini sangat dimungkinkan munculnya presiden yang dicalonkan oleh partai politik yang memperoleh kursi minoritas di lembaga perwakilan, hal seperti itu sangat mungkin terjadi dalam sistem multipartai. Oleh karena pemilihan umum yang dilaksanakan secara terpisah dan presiden terpilih belum tentu memperoleh dukungan politik dari legislatif, maka sangat mungkin akan terjadi deadlock dalam persidangan dan pelaksanaan tugas-tugas ketatanegaraan yang mengakibatkan terjadinya ketegangan antara presiden dengan legislatif. ${ }^{13}$

Dualisme legitimasi politik ini akan sangat berpengaruh dalam sistem multipartai dimana konflik antara presiden dengan lembaga perwakilan merupakan masalah kebijakan politik presiden yang tidak diterima oleh lembaga perwakilan. Karena secara politis kedua lembaga ini dipilih langsung oleh rakyat, maka dikhawatirkan yang muncul adalah politik pengerahan massa untuk memperlemah kedudukan politik lembaga negara berskaitan dengan lembaga mana yang lebih memiliki hak guna menyuarakan suara rakyat. Kondisi deadlock dalam sistem presidensial akan semakin rumit karena presiden memiliki masa jabatan yang pasti (fixed term) yang dilindungi oleh konstitusi serta lembaga legislatif juga tidak dapat dibubarkan untuk segera diselenggarakan pemilihan umum. ${ }^{14}$

Dalam pemilihan presiden secara langsung oleh rakyat yang berlaku adalah sistem winner takes all atau mayoritas sederhana, yakni calon yang memperoleh suara $50 \%$ plus satu akan ditetapkan sebagai pemenang. Dalam Undang-Undang Dasar Negara Republik Indonesia 1945 Pasal 6A ayat (3) menyebutkan bahwa pasangan calon Presiden dan Wakil Presiden yang mendapatkan suara lebih dari 50\% dari jumlah suara dengan sedikitnya dua puluh $25 \%$ suara tersebar di lebih dari setengah jumlah propinsi di Indonesia ditetapkan sebagai pemenang. Dengan ketentuan seperti ini merupakan sistem mayoritas sederhana (simple majority system). Dalam kerangka sistem multipartai dimana tidak ada partai politik yang dominan, maka secara teoritis akan muncul banyak pasangan calon presiden. Meskipun syarat pencalonan presiden hanya bisa dilakukan oleh partai politik atau gabungan partai politik yang memperoleh jumlah kursi atau jumlah suara tertentu, berdasarkan Undang Undang Nomor 7 tahun 2017 tentang Pemilihan Umum yang mensyaratkan sebesar 20\% kursi legislatif atau $25 \%$ suara sah nasional pada pemilihan umum sebelumnya. Secara teoritis maka akan dapat memunculkan 4 (empat) calon presiden dan wakil presiden.

Permasalahan akan muncul apabila pemilihan umum presiden dan wakil presiden tidak menghasilkan presiden terpilih dalam satu putaran dan pada putaran kedua yang memenangkan pemilihan umum bukan calon yang memenangkan pemilihan pada putaran pertama. Contoh: empat pasang calon Presiden dan Wakil Presiden yakni a, b, dan c. Pada putaran pertama menghasilkan komposisi suara A memperoleh $45 \%$ suara, b memperoleh $35 \%$, dan c memperoleh $25 \%$ suara. Kemudian

13 Fuad Putra Perdana Ginting dan Anwar Saragih, "Ilusi Demokrasi Substansial di Indonesia: Sebuah Kritik Terhadap Impementasi Parliamentary Treshlod," Politeia: Jurnal Ilmu Politik 10, no. 2 (2018): 17.

14 Ramadhan, Muhammad Febry. "Politik Hukum Penyederhanaan Sistem Kepartaian Di Indonesia," Lex Renaissance 3, no. 1 (2018): 8. 
berdasarkan ketentuan Pasal 6A ayat (4) pasangan A dan pasangan B akan dipilih kembali dalam pemilihan putaran kedua, dan ternyata dalam putaran kedua B memenangkan pemilihan tersebut. ${ }^{15}$

Dalam situasi penggabungan multi partai dalam sistem presidensial akan mempengaruhi hubungan antara Lembaga kepresidenan dan lembaga legislatif dalam pembentukan Undang Undang. Pembentukan Undang Undang sebelum Perubahan Undang Undang Dasar 1945 dalam Pasal 5 ayat (1) menyebutkan bahwa kekuasaan membentuk Undang Undang berada di tangan Presiden dengan persetujuan DPR. Setelah Perubahan UUD 1945 kekuasaan membuat Undang Undang berada di tangan DPR. Perubahan atau pergeseran kekuasaan pembuatan Undang Undang ini merupakan implementasi asas pemisahan kekuasaan dan mengembalikan kekuasaan legislasi ke tangan DPR. ${ }^{16}$

Sistem multi partai adalah salah satu varian dari beberapa sistem kepartaian yang berkembang di dunia modern saat ini. Andrew Heywood berpendapat bahwa sistem partai politik adalah sebuah jaringan dari hubungan dan interakasi antara partai politik di dalam sebuah sistem politik yang berjalan. ${ }^{17}$ Untuk mempermudah memahami sistem partai politik Heywood kemudian memberikan kata kunci untuk membedakan tipe-tipe sistem kepartaian. Kata kunci tersebut adalah jumlah partai politik yang tumbuh atau eksis yang mengikuti kompetisi mendapatkan kekuasaan melalui pemilu. ${ }^{18}$ Parameter "jumlah partai politik" untuk menentukan tipe sisem partai politik pertama kali dikenalkan dan dipopulerkan oleh Duverger pada tahun 1954 dimana Duverger membedakan tipe sitem politik menjadi 3 sistem, yaitu sistem partai tunggal, sistem dua partai, dan sistem multi partai.

Padahal konsep koalisi partai politik Indonesia dalam sistem presidensil memberikan gambaran bahwa kekuasaan presiden dapat terbatas dikarenakan adanya kompromi-kompromi politik antarpartai politik dan Presiden yang tergabung dalam koalisi pemerintah. ${ }^{19}$ Koalisi yang dibentuk oleh pemerintah (Presiden beserta partai pengusung), dibagi berdasarkan komposisi kursi diparlemen dan dukungan partai selama Pilpres (Pemilu Presiden). Hal ini berimbas pada komposisi jumlah menteri di dalam kabinet pemerintah. Pembentukan koalisi diharapakan akan memberikan kestabilan terhadap agenda politik dan kerja presiden dikarenakan dukungan politik di parlemen yang kuat. ${ }^{20}$ Dengan demikian, solidnya koalisi dapat didasarkan pada kesamaan tujuan dan agenda politik bersama di antara koalisi partai politik.

\subsection{Rumusan Masalah}

Berdasarkan latar belakang tersebut, rumusan masalah yang akan dijawab di dalam penelitian ini adalah sebagai berikut:

15 Mary Somers Heidhues, "Violent, political, and administrative repression of the Chinese minority in Indonesia, 1945-1998," Wacana 18, no. 1 (2017): 19.

16 Mexsasai Indra, "Gagasan Penyederhanaan Jumlah Partai Politik Dihubungkan Dengan Sistem Pemerintahan Republik Indonesia," Jurnal Ilmu Hukum 1, no. 2 (2011): 19.

17 Kholis, Nur. "Parliamentary Threshold and Political Rights Limitation," Journal of Law and Legal Reform 1, no. 3 (2020): 21.

18 Ginting dan Saragih, "Ilusi Demokrasi Substansial di Indonesia," 7.

19 Ufen, Andreas. "Party presidentialization in post-Suharto Indonesia," Contemporary Politics 24, no. 3 (2018): 17.

20 Robert Lowry, Indonesia: From Suharto to Democracy? (Canberra, ACT: Dept. of Political and Social Change, Research School of ..., 2017), 213. 
1. Apakah politik hukum terkait praktik koalisi partai ini dapat mencapai citacita hukum seperti representasi akurat dari preferensi pemilih dan pemerintah yang stabil serta bertanggung jawab?

2. Apa upaya dalam praktik ketatanegaraan yang dapat merealisasikan stabilitas sistem pemerintahan presidensial pada koalisi di multi partai?

\subsection{Tujuan Penulisan}

Adapun tujuan penulisan penelitian ini adalah untuk mengetahui politik hukum terkait praktik koalisi partai politik di Indonesia serta untuk mengetahui upaya-upaya dalam praktik ketatanegaraan yang dapat merealisasikan stabilitas sistem pemerintahan presidensial pada koalisi di multi partai

\section{Metode Penelitian}

Penelitian ini adalah penelitian hukum normatif yang dilakukan menggunakan penelitian kepustakaan untuk mendapatkan data sekunder dengan bahan atau materi berupa buku-buku, artikel-artikel, hasil-hasil penelitian, dan pendapat ahli yang berkaitan dengan praktik koalisi partai politik di Indonesia. Pengumpulan data dilakukan dengan studi dokumen dan literatur-literatur yang berkaitan dengan tema penelitian untuk mendapatkan data berkaitan dengan dengan praktik koalisi partai politik di Indonesia dengan, Pertama, bahan primer, yang mencakup peraturan perundang-undangan yang berlaku, yurisprudensi yang berkaitan dengan pokok permasalahan penelitian. Kedua bahan sekunder, terdiri dari hasil-hasil penelitian yang telah ada sebelumnya yang terkait dengan permasalahan penelitian dan kepustakaan. Berdasarkan data dan informasi yang sudah diperoleh, akan dilakukan analisis kualitatif yakni suatu cara penelitian yang menghasilkan data deskriptif analitis, yaitu apa yang ditemukan dalam praktek dan literatur diteliti dan dipelajari sebagai sesuatu yang utuh.

\section{Hasil dan Pembahasan}

\subsection{Politik Hukum Koalisi Partai Politik di Indonesia}

\subsubsection{Sistem Presidensial dalam Sistem Multi Partai}

Sistem pemerintahan presidensial yang berada di dalam suatu negara heterogen dengan multipartai menjadi sangat tidak efektif. Hal ini terjadi karena polarisasi masyarakat yang dimanifestasikan dalam parlemen, menjadikan sebuah parlemen yang bersifat cair, mudah berubah dan sangat fleksibel. ${ }^{21}$ Sehingga praktik ini sangat berlawanan dengan hakikat kekuasaan eksekutif pemerintahan presidensial yang bersifat rigid. Rigiditas eksekutif ini tercermin dengan masa jabatan fixed term dan Presiden yang tidak dapat dijatuhkan oleh legislatif., akan membuat frustasi rakyat yang harus menunggu sampai masa jabatan Presiden berakhir baru kemudian memilih kembali Presiden dalam pemilihan umum.

Dalam pemerintahan presidensial pemilihan umum dilaksanakan dua kali, yakni pemilihan anggota legislatif dan pemilihan Presiden. ${ }^{22}$ Presiden memegang kekuasaan untuk menjalankan pemerintahan, sehingga pemilihan umum Presiden menjadi sangat penting yang menentukan arah kebijakan negara. Dalam sistem ini, partai politik dalam pemilihan umum di pemerintahan presidensial lebih bersifat

21 Hanta Yuda AR, Presidensialisme Setengah Hati (Gramedia Pustaka Utama, 2013), 119.

22 Surbakti, R. dan Nugroho, K. "Studi Tentang Desain Kelembagaan Pemilu yang Efektif," 2015, 19. 
sebagai penopang atau pendukung bagi program calon presiden yang didukungnya. Dengan demikian partai politik cenderung menjadi kendaraan politik untuk memperoleh kedudukan atau jabatan politik. ${ }^{23}$ Selain itu, popularitas calon presiden menjadi faktor terpenting dalam model pemilihan umum ini dibandingkan dengan program partai politik. ${ }^{24}$

Tak dapat dipungkiri, banyak sekali ditemukan kelemahan dalam partai politik di Indonesia, terutama terhadap kurangnya kemampuan untuk membangun kapasitas dan integritas kelembagaan. Paling tidak ada empat hal yang menyebabkan hal tersebut. Pertama, proses rekrutmen anggota partai maupun pimpinan partai, khususnya di tingkat bawah tidak diatur secara utuh dan sistematis. Kedua, tidak ada aturan yang komprehensif yang mengatur seorang anggota baru untuk bisa duduk di dalam jajaran fungsionaris dan struktur partai. Ketiga, mekanisme komunikasi antara kader partai dan anggota parlemen dengan konstituennya atau rakyat untuk memahami aspirasi yang berkembang di masyarakatnya tidak cukup diatur dan tidak dilakukan. Keempat, proses pengkaderan partai yang dilakukan secara berjenjang untuk memahami ideologi dan program strategis partai serta peningkatan kemampuan kepemimpinan dilakukan tidak serius dan konsisten. ${ }^{25}$

Dalam sistem pemerintahan presidensial dengan multipartai, dengan tidak ada partai politik yang memperoleh suara mayoritas dalam pemilihan umum. Maka dalam pembentukan kabinet Presiden harus mempertimbangkan keikutsertaan partai politik lain dalam suatu koalisi. Akan tetapi koalisi ini tidak bersifat permanen karena menteri bertanggungjawab langsung kepada Presiden dan tidak kepada parlemen. Oleh karena itu partai politik dalam parlemen tidak mempunyai kewajiban untuk mendukung pemerintah, meskipun memiliki wakil di kabinet.

Dua pemilihan umum dalam sistem presidensial merupakan pemilihan umum yang terpisah dan tidak berkaitan sama sekali, sehingga dalam sistem ini sangat dimungkinkan munculnya presiden yang dicalonkan oleh partai politik yang memperoleh kursi minoritas di lembaga perwakilan, hal seperti itu sangat mungkin terjadi dalam sistem multipartai. Oleh karena pemilihan umum yang dilaksanakan secara terpisah dan presiden terpilih belum tentu memperoleh dukungan politik dari legislatif. Sehingga hal ini memungkinkan terjadinya deadlock dalam persidangan dan pelaksanaan tugas-tugas ketatanegaraan yang mengakibatkan terjadinya ketegangan antara presiden dengan legislatif.

Dualisme legitimasi politik ini akan sangat berpengaruh dalam sistem multipartai, dimana konflik antara presiden dengan lembaga perwakilan merupakan masalah kebijakan politik presiden yang tidak diterima oleh lembaga perwakilan. ${ }^{26}$ Karena secara politis kedua lembaga ini dipilih langsung oleh rakyat, maka dikhawatirkan yang muncul adalah politik pengerahan massa untuk memperlemah kedudukan politik lembaga negara berskaitan dengan lembaga mana yang lebih

23 Isra, Saldi. "Pemilihan Presiden Langsung dan Problematik Koalisi Dalam Sistem Presidensial," Jurnal Konstitusi, 2009, 19.

24 Romli, Lili. "Koalisi dan Konflik Internal Partai Politik pada Era Reformasi," Jurnal Politica Dinamika Masalah Politik Dalam Negeri dan Hubungan Internasional 8, no. 2 (2018): 14.

25 Mulyosudarmo, S. Pembaharuan Ketatanegaraan Melalui Perubahan Konstitusi, Editor; A. Mukti Fajar dan Harjono, Asosiasi Pengajar HTN dan HAN Jawa Timur dan In-TRANS, Cetakan Pertama, Bandung, Pebruari 2004, 4.

26 Hendra Sunandar, "Analisis sistem presidensialisme-multipartai di Indonesia: studi atas divided government dalam relasi eksekutif-legislatif pemerintahan Joko Widodo-Jusuf Kalla," 2015, 41. 
memiliki hak guna menyuarakan suara rakyat. Kondisi deadlock dalam sistem presidensial akan semakin rumit karena presiden memiliki masa jabatan yang pasti (fixed term) yang dilindungi oleh konstitusi serta lembaga legislatif juga tidak dapat dibubarkan untuk segera diselenggarakan pemilihan umum. ${ }^{27}$

Dalam situasi penggabungan multi partai dalam sistem presidensial akan mempengaruhi hubungan antara Lembaga kepresidenan dan lembaga legislatif dalam pembentukan Undang Undang. Pembentukan Undang Undang sebelum Perubahan Undang Undang Dasar 1945 dalam Pasal 5 ayat (1) menyebutkan bahwa kekuasaan membentuk Undang Undang berada di tangan Presiden dengan persetujuan DPR. Setelah Perubahan UUD 1945 kekuasaan membuat Undang Undang berada di tangan DPR. Perubahan atau pergeseran kekuasaan pembuatan Undang Undang ini merupakan implementasi asas pemisahan kekuasaan dan mengembalikan kekuasaan legislasi ke tangan DPR.

Perubahan Undang-Undang Dasar Negara Republik Indonesia 1945 tersebut tidak memberikan hak veto bagi Presiden untuk menolak sebuah rancangan Undang Undang yang telah disetujui. Padahal dalam sistem presidensial setiap kekuasaan memiliki mekanisme checks and balances untuk mencegah terjadinya dominasi kekuasaan di tangan satu lembaga negara. ${ }^{28}$ Persetujuan bersama dalam pembahasan Rancangan Undang Undang tidak dapat dijadikan acuan bahwa presiden juga menyetujui Rancangan Undang Undang tersebut, hal ini karena praktik pemerintahan di negara modern tidak memungkinkan presiden untuk melakukan pembahasan Rancangan Undang Undang bersama DPR secara langsung akan tetapi presiden mendelegasikannya kepada bawahannya dalam hal ini adalah menteri yang membidangi Rancangan Undang Undang tersebut. ${ }^{29}$ Persetujuan pemerintah dalam pembahasan Rancangan Undang Undang yang diwakili oleh menteri seharusnya disetujui terlebih dahulu oleh presiden sebelum diundangkan, karena Presiden dalam sistem pemerintahan presidensial merupakan pejabat yang bertanggungjawab kepada rakyat terhadap kebijakan yang diambil kabinetnya, karena menteri bertanggungjawab langsung kepada presiden. Hubungan yang tercipta antara Presiden dengan DPR menurut Syamsuddin Haris merupakan hubungan yang bersifat politik-transaksional, hal ini dikarenakan dukungan riil politik presiden di parlemen merupakan minoritas dan fragmentasi partai politik di parlemen yang lebar. ${ }^{30}$

Oleh karena itu untuk memperoleh dukungan parlemen Presiden harus membuka ruang kompromi yang besar dengan kepentingan-kepentingan tersebut. Hal ini disinyalir menjadikan produk legislasi Presiden dan DPR banyak memiliki kelemahan karena sarat dengan kepentingan sesaat hasil dari kompromi yang luas. Hal ini paling tidak dapat dilihat dari banyaknya gugatan judicial review materi Undang Undang yang diajukan ke Mahkamah Konstitusi. Undang Undang merupakan produk yang menjelmakan secara normatif kehendak politik DPR dengan pemerintah. Karena itu masuknya pertimbangan atau kepentingan politik merupakan

27 I. Gede DE Adi Atma Dewantara dan Dewa Gde Rudy, "Implikasi Hukum Koalisi Partai Politik dalam Membentuk Pemerintahan yang Efektif," Kertha Negara: Journal Ilmu Hukum, t.t., 81.

28 Zuhdi Arman, “Tinjauan Terhadap Sistem Multi Partai Dalam Sistem Pemerintahan Presidensial Di Indonesia Pada Era Reformasi," Jurnal Cahaya Keadilan 6, no. 1 (2018): 18.

29 Imam Yudhi Prasetya, "Pergeseran Peran Ideologi Dalam Partai Politik," Jurnal Ilmu Politik dan Ilmu Pemerintahan 1, no. 1 (2011): 24.

30 Bagir Manan, Dpr, Dpd, Dan Mpr Dalam Uud 1945 Baru (FH-Uii Press, 2003), 24. 
sesuatu yang wajar. Akan tetapi masuknya kepentingan politik ini seharusnya tidak sampai menjadikannya sebagai suatu UU just for the sake politics. ${ }^{31}$

Indonesia menganut sistem multi partai. Indonesia menerapkan secara bersamasama sistem multipartai dan sistem pemilihan umum proportional representation yang berakibat sulitnya memperoleh suara mayoritas di parlemen dan majority government. Keadaan demikian mengakibatkan lahirnya koalisi partai yang terjadi di Indonesia dewasa ini. Sistem multipartai dengan jumlah partai sangat banyak perlu segera di dorong menjadi multipartai sederhana, terutama jumlah partai di parlemen. Multipartai dengan jumlah partai yang banyak perlu perubahan secara institusional menjadi sistem multipartai sederhana sehingga implikasi dalam penggabunga multi partai di tengah sistem presidensial dapat diredam.

\subsubsection{Implikasi Penerapan Sistem Multipartai dalam Sistem Presidensial di Indonesia}

Dalam perubahan Undang Undang Dasar 1945 mengenai pembentukan Dalam perubahan Undang Undang Dasar 1945 mengenai pembentukan Undang Undang ini diatur dalam Pasal 20 yang berbunyi sebagai berikut ini diatur dalam Pasal 20 yang berbunyi sebagai berikut:

a. Dewan Perwakilan Rakyat memegang kekuasaan membentuk undangundang;

b. Setiap rancangan undang-undang dibahas oleh Dewan Perwakilan Rakyat dan Presiden untuk mendapat persetujuan bersama;

c. Jika rancangan undang-undang itu tidak mendapat persetujuan bersama, rancangan undang-undang itu tidak boleh diajukan lagi dalam persidangan Dewan Perwakilan Rakyat masa itu;

d. Presiden mengesahkan rancangan undang-undang yang telah disetujui bersama untuk menjadi undang-undang;

e. Dalam hal rancangan undang-undang yang telah disetujui bersama tersebut tidak disahkan oleh Presiden dalam waktu tiga puluh hari semenjak rancangan undang-undang tersebut disetujui, rancangan undang-undang tersebut sah menjadi undang-undang dan wajib diundangkan.

Kemudian dalam ketentuan Undang-Undang Dasar Negara Republik Indonesia 1945 Pasal 5 ayat (1) menyebutkan bahwa Presiden berhak mengajukan rancangan undang-undang kepada DPR. Dari ketentuan ini dan ketentuan pasal 20 di atas dapat diketahui bahwa terdapat pergeseran kekuasaan membentuk Undang Undang dari tangan Presiden ke tangan DPR.

Permasalahannya adalah dalam perubahan Undang-Undang Dasar Negara Republik Indonesia 1945 tersebut tidak adanya hak veto bagi Presiden untuk menolak sebuah rancangan Undang Undang yang telah disetujui. Padahal dalam sistem presidensial setiap kekuasaan memiliki mekanisme check and balances untuk mencegah terjadinya dominasi kekuasaan di tangan satu lembaga negara. Persetujuan bersama dalam pembahasan Rancangan Undang Undang tidak dapat dijadikan acuan bahwa presiden juga menyetujui Rancangan Undang Undang tersebut, hal ini karena praktek pemerintahan di negara modern tidak memungkinkan presiden untuk melakukan pembahasan Rancangan Undang Undang bersama DPR secara langsung akan tetapi presiden mendelegasikannya kepada bawahannya dalam hal ini adalah menteri yang membidangi Rancangan Undang Undang tersebut. Persetujuan

31 Manan, Bagir. Op.Cit., 27-28. 
pemerintah dalam pembahasan Rancangan Undang Undang yang diwakili oleh menteri seharusnya disetujui terlebih dahulu oleh presiden sebelum diundangkan, karena Presiden dalam sistem pemerintahan presidensial merupakan pejabat yang bertanggungjawab kepada rakyat terhadap kebijakan yang diambil kabinetnya, karena menteri bertanggungjawab langsung kepada presiden. Hubungan yang tercipta antara Presiden dengan DPR menurut Syamsuddin Haris merupakan hubungan yang bersifat politik-transaksional, hal ini dikarenakan dukungan riil politik presiden di parlemen merupakan minoritas dan fragmentasi partai politik di parlemen yang lebar.

Oleh karena itu untuk memperoleh dukungan parlemen Presiden harus membuka ruang kompromi yang besar dengan kepentingan-kepentingan tersebut. Hal ini disinyalir menjadikan produk legislasi Presiden dan DPR banyak memiliki kelemahan karena sarat dengan kepentingan sesaat hasil dari kompromi yang luas. Hal ini paling tidak dapat dilihat dari banyaknya gugatan judicial review materi Undang Undang yang diajukan ke Mahkamah Konstitusi. Undang Undang merupakan produk yang menjelmakan secara normatif kehendak politik DPR dengan pemerintah. Karena itu masuknya pertimbangan atau kepentingan politik merupakan sesuatu yang wajar. Akan tetapi masuknya kepentingan politik ini seharusnya tidak sampai menjadikannya sebagai suatu undang-undang yang bermuatan kepentingan politik.

Indonesia menganut sistem multi partai. Indonesia menerapkan secara bersamasama sistem multipartai dan sistem pemilihan umum proportional representation yang berakibat sulitnya memperoleh suara mayoritas di parlemen dan majority government. Keadaan demikian mengakibatkan lahirnya koalisi partai yang terjadi di Indonesia dewasa ini. Sistem multipartai dengan jumlah partai sangat banyak perlu segera di dorong menjadi multipartai sederhana, terutama jumlah partai di parlemen. Multipartai dengan jumlah partai yang banyak perlu perubahan secara institusional menjadi sistem multipartai sederhana sehingga implikasi dalam penggabunga multi partai di tengah sistem presidensial dapat diredam.

Terdapat 3 (tiga) cara yang harus dilakukan meredam implikasi yang terjadi di tengah sistem Multi Partaidalam sistem presidensial, yaitu:

Pertama, Penyederhanaan partai politik perlu dilakukan karena sistem multi partai dalam pemilu di Indonesia telah berkonsekuensi membludaknya partai politik yang ingin mengikuti pemilu. Dengan mereformasi sistem pemilu, penyederhanaan jumlah partai politik dapat ditempuh melalui beberapa agenda rekayasa institusional (institutional engineering), antara lain: menerapkan sistem pemilu distrik (plurality/majority system) atau sistem campuran (mixed member proportional), memperkecil besaran daerah pemilihan (distric magnitude), menerapkan ambang batas kursi di parlemen (parliamentary threshold) secara konsisten, dan menggabungkan pelaksanaan pemilu legislatif dan pemilu presiden. Indonesia telah menerapkan 2 dua alternative guna penyederhanaan partai politk dengan menerapkan ambang batas kursi di parlemen (parliamentary threshold) secara konsisten, dan menggabungkan pelaksanaan pemilihan legislatif dan pemilihan Presiden.

Kedua, Desain pelembagaan koalisi. Pada era Reformasi, kecenderungan koalisi partai dalam kehidupan politik Indonesia mulai terbangun pasca-Pemilu 1999, yaitu dalam pemilihan presiden dan wakil presiden oleh MPR. Koalisi dalam bentuk Poros Tengah, yang dimotori PAN dan PPP berhasil menaikkan Abdurahman Wahid sebagai presiden pertama era Reformasi. Dalam sistem 
pemerintahan presidensial yang multipartai, koalisi adalah suatu hal yang tidak bisa ditawar tawar untuk membentuk pemerintahan yang kuat. Kareana dalam sistem presidensial yang berpadu dengan multipartai meniscayakan terbentuknya koalisi antar partai dalam mengusung calon presiden karena hampir dapat dipastikan bahwa sistem multipartai sulit menghasilkan partai yang memenangkan suara mayoritas.

Ketiga, Pengaturan pelembagaan terhadap partai politik yang memilih menjadi oposisi perlu dilakukan, guna menjadi penyeimbnag dalam jalannya pemerintahan. Istilah oposisi telah menjadi bagian dalam wacana politik di Indonesia sejak dimulainya era presidensialisme multipartai. Tetapi istilah ini tampaknya dipahami secara beragam. Sebagian pengamat politik sering menghubungkan oposisi dengan sistem parlementer sehingga menganggapnya asing bagi sistem presidensial. Dengan adanya partai oposisi, akan bisa dihindari praktek-prakteik politik yang bersekongkol antara pemerintah dan para anggota legistatif dan praktek politik uang atau suap untuk mengegolkan kebijakan pemerintah kecil kemungkinan bisa dilakukan.

\subsection{Cita Hukum Indonesia dan Upaya Merealisasikan Stabilitas Sistem Pemerintahan Presidensial pada Koalisi Multi Partai}

Secara konstitusional, Negara Republik Indonesia menganut sistem Presidensial yang berarti bahwa pemegang kendali dan penanggung jawab jalannya pemerintahan negara (kepala eksekutif) adalah Presiden. ${ }^{32}$ Sistem presidensial di Indonesia dikombinasikan dengan sistem multipartai di Indonesia merupakan implementasi tuntutan reformasi terhadap kebebasan berpartai atau mendirikan partai politik.

Pasal 6A ayat (2) UUD NRI 1945 menyatakan:

"Pasangan calon Presiden dan Wakil Presiden diusulkan oleh partai politik atau gabungan partai politik peserta pemilihan umum sebelum pelaksanaan pemilihan umum."

Ketentuan lain yang secara eksplisit mengatur koalisi terdapat dalam Pasal 8 ayat (3) UUD NRI Tahun 1945 menyatakan:

"Jika Presiden dan Wakil Presiden mangkat, berhenti, diberhentikan, atau tidak dapat melakukan kewajibannya dalam masa jabatannya secara bersamaan, Pelaksana Tugas Kepresidenan adalah Menteri Luar Negeri, Menteri Dalam Negeri, Menteri Pertahanan secara bersama-sama. Selambat- lambatnya tiga puluh hari setelah itu, Majelis Permusyawaratan Rakyat menyelenggarakan sidang untuk memilih Presiden dan Wakil Presiden dari dua paket calon Presiden dan Wakil Presiden yang diusulkan oleh partai politik atau gabungan partai politik yang paket calon Presiden dan Wakil Presidennya rneraih suara terbanyak pertama dan kedua dalam pemilihan sebelumnya, sampai habis masa jabatannya."

Berdasarkan ketetntuan di atas, konstitusi menghendaki koalisi partai politik yang terjadi sebelum pemilihan (pre-electoral coalition) seperti yang terdapat dalam Pasal 6A ayat (2) Undang Undang Dasar Negara Republik Indonesia Tahun 1945 berlangsung secara permanen sepanjang jalannya pemerintahan hasil pemilihan umum. Alasannya, kondisi yang dimaksud dalam Pasal 8 ayat (3), kekosongan jabatan presiden dan wakil presiden secara bersamaan, dapat terjadi kapan saja sepanjang berjalannya pemerintahan hasil pemilihan umum. Melihat karakter sistem

32 Sebagaimana tercantum dalam Pasal 4 ayat (1) UUD NRI 1945. Sedangkan menteri hanyalah sebagai pembantu Presiden. 
pemerintahan presidensil, ketentuan dalam konstitusi tersebut nampak memiliki masalah. Koalisi pemerintahan (government coalition) dalam sistem presidensil memiliki potensi perubahan cukup tinggi dan perubahan dalam koalisi bukan berarti pergantian kekuasaan eksekutif. Kekuasaan eksekutif di sistem presidensil sumber legitimasinya bukan dari parlemen tetapi memiliki legitimasi langsung dari rakyat. Oleh karena itu, koalisi yang terbentuk sebelum pemilihan presiden (pre-electoral coalition) sebagaimana dimaksud Pasal 6A ayat (2) bisa berubah sehingga berbeda dengan komposisi koalisi yang memerintah (government coalition). Dalam perjalanan pemerintahan komposisi koalisi dapat terus berubah sehingga jika terjadi kondisi sebagaimana dimaksud Pasal 8 ayat (3) maka koalisi yang yang terjadi berdasar Pasal 6A ayat (2) bisa jadi sudah benar-benar berbeda. Dalam kondisi demikian maka akan sulit melaksanakan ketentuan dalam Pasal 8 ayat (3) Undang Undang Dasar Negara Republik Indonesia Tahun 1945.

Kombinasi antara sistem presidensil dengan sistem multipartai banyak menghadirkan persoalan karena anggota lembaga legislatif dan presiden dipilih secara langsung oleh rakyat (pemilih). Seringkali kombinasi antara kedua sistem tersebut dapat menyebabkan disharmonisasi atau terjadi ketidakselarasan antara lembaga eksekutif dan lembaga legislatif yang bisa mengarah pada kebuntuan antar kedua lembaga tersebut apabila yang menguasai lembaga kepresidenan dan yang menguasai parlemen dari partai yang berbeda. Salah satu kelemahan sistem presidensial yang multipartai dalam hal ini adalah ketegangan antara lembaga eksekutif dan lembaga legislatif. Seringkali presiden tidak dapat menyelesaikan agenda agendanya akibat kurangnya dukungan dalam parlemen dan banyaknya intrupsi atas usulan usulan presiden baik yang bersifat legislasi maupun non legislasi.

Dalam sistem presidensil, koalisi sebagai cara pembentukan dan pengelolaan pemerintahan lazimnya tidak terinstitusionalisasi dalam kerangka hukum. Koalisi dianggap sebagai mekanisme politik yang terjadi sebagai akibat dari proses tawar menawar atau negosiasi dalam rangka upaya memenangkan pemilihan umum (preelectoral coalition) dan dalam rangka pengelolaan pemerintahan yang stabil terutama ketika pemerintah berhadapan dengan lembaga legislatif (government coalition). Namun, sistem presidensil Indonesia nampak memberi tempat koalisi dalam aturan konstitusinya. Pemilihan presiden langsung yang menjadi salah satu ciri penting sistem presidensil yang dianut Indonesia menyatakan bahwa proses pencalonannya dapat dilakukan oleh koalisi partai politik

Dengan situasi seperti itu, banyak kalangan meragukan kelangsungan dan stabilitas pemerintah dalam sistem presidensial yang multipartai. Misalnya. Jose A. Cheibub, Adam Przeworzki, dan Sebastian M. Saiegh dalam tulisan "Government Coalitions and Legislative Success Under Presidentialism and Parliamentarism" mencatat banyak pendapat yang meragukan kelangsungan dan stabilitas pemerintahan presidensil dalam sistem multipartai. ${ }^{33}$

Perubahan Undang-Undang Dasar 1945 menimbulkan implikasi yang cukup mendasar terhadap ketatanegaraan Indonesia, tidak saja terhadap pelaksanaan prinsip kedaulatan rakyat, struktur, kedudukan dan hubungan antar lembaga- lembaga atau organ-organ negara, tetapi juga terhadap sistem pemerintahannya. Terkait sistem pemerintahan, yang menjadi tuntutan dari reformasi tersebut adalah mempertegas

33 José Antonio Cheibub, Adam Przeworski, dan Sebastian M. Saiegh, "Government coalitions and legislative success under presidentialism and parliamentarism," british Journal of political science 34 , no. 4 (2004): 565-566. 
sistem pemerintahan presidensil didalam Undang-Undang Dasar 1945 dan mewujudkan kerangka mekanisme check and balances, khususnya diantara lembaga legislatif dan eksekutif. Mempertegas dalam hal ini juga meliputi penyempurnaan sistem penyelenggaraan pemerintahan agar benar-benar memenuhi prinsip dasar sistem presidensial. Dalam Undang-Undang Dasar Negara Republik Indonesia 1945 koalisi partai politik ikut andil dalam mempengaruhi sistem presidensial Indonesia, elemen utama dalam sistem checks and balances adalah kejelasan langsung peranan presiden dalam proses legislasi.

Namun, setelah diamandennya Undang-Undang Dasar Negara Republik Indonesia 1945 persoalan tidak kunjung berhenti, perdebatan terus berlangsung baik itu diantara para akademisi, ahli tata negara maupun para politisi. Salah satu Persoalan yang muncul sampai hari ini adalah terkait dengan dibentuknya koalisi partai politik dalam pemerintahan pada saat pergantian era kepresidenan. Pembentukan koalisi dikarenakan tidak adanya partai politik yang mendominasi jumlah perolehan suara. Koalisi bertujuan guna mencalonkan calon Presiden dan wakil presiden, serta menjaga stabilitas pemerinthan. Koalisi yang awalnya memang fitur dalam sistem parlementer yang terjadi apabila dalam hasil pemilihan umum menujukkan tidak adanya partai politik yang mendapat mayoritas suara. Perbedaan koalisi antara kedua sistem pemerintahan tersebut diantaranya, kedudukan presiden yang tidak bergantung pada mayoritas legislatif (legislative majority) membuat presiden bebas membentuk dan mengganti koalisi sekehendaknya dan perubahan tersebut tanpa adanya perubahan kekuasaan,34 Partai pembentuk koalisi di sistem parlementer belum dapat segera dipastikan dengan melihat hasil pemilihan umum sedangkan di sistem presidensil, partai pengusung presiden dapat dipastikan sebagai pembentuk koalisi. Dalam sistem parlementer, partai politik pemenang pemilihan umum memang lazimnya bertindak sebagai formatur pembentuk kabinet namun tetap memiliki potensi gagal sehingga digantikan partai terbanyak berikutnya dan begitu seterusnya. Dengan kontruksi seperti itu maka ada kemungkinan partai terbesar malah bukanlah peserta koalisi pemerintahan yang akhirnya terbentuk karena formatur pembentuk kabinet dapat mengecualikan partai manapun termasuk partai terbesar. Sedangkan di dalam sistem presidensil, partai pengusung presiden selalu ikut dalam koalisi pemerintahan, ${ }^{35}$ di sistem parlementer, jika koalisi pemerintahan gagal terbentuk maka akan terjadi krisis pemerintahan yang dapat berakibat terjadinya percepatan pemilihan umum atau dalam situasi tertentu sistem ini dapat menerima pemerintahan yang terdiri dari para orang- orang non partisan yang bertindak sebagai pengganti pemerintahan (caretaker government). Di sistem presidensil tidak dikenal percepatan pemilihan umum baik untuk pemilihan anggota legislatif maupun untuk pemilihan presiden. Jika tidak ada koalisi yang terbentuk maka partai presiden akan mengambil semua jabatan dalam kabinet atau mendistribusikan sekehendaknya. ${ }^{36}$

Pemilu 1999 merupakan pemilu pertama pasca reformasi. Kebebasan berpartai politik ini terekspresi dengan banyaknya jumlah partai politik, ada 180 partai baru berdiri, meskipun hanya 142 partai yang dapat didaftarkan, dan hanya 48 yang lolos

34 Ibid, 566.

35 Ibid, 567.

36 Ibid 
penyaringan dan ikut bertarung dalam pemilu 1999.37 Pada era Presiden Susilo Bambang Yudhoyono pada tahun 2004 dimana, dalam pemilihan presiden, pasangan Susilo Bambang Yudhoyono Jusuf Kalla (SBY-JK) mendapat dukungan 69.266.350 $(60.62 \%)$ suara sah dan pasangan Megawati Soekarnoputri Hasyim Muzadi memperoleh $44.990 .704(39,38 \%)$ suara sah secara nasional. Jika hasil itu diletakkan di tingkat provinsi, SBY-JK unggul di 28 provinsi atau $88 \%$ dan pasangan MegaHasyim hanya mampu menguasai 4 provinsi atau $12 \%$ dari jumlah provinsi yangada, akan tetapi pasanagan SBY-JK hanya mendapatkan $12 \%$ suara di DPR. ${ }^{38}$ Hingga era Presiden Joko Widodo pada Pemilihan Umum 2014 yang diikuti oleh calon presiden dan wakil presiden Prabowo Subianto- Hatta Rajasa.yang didukung oleh oleh 6 (enam) partai politik dan pasangan kedua yaitu pasanagan Joko Widodo-Jusuf Kalla yang didukung oleh koalisi 5 (lima) partai politik. Pemilihan Presiden 2014 dimenangkan oleh pasanagan Joko Widodo dengan perolehan suara $70.997 .850(53.15 \%)$, sedangkan pasangan Prabowo Subianto-Hatta Rajasa meraih suara 62.576 .444 (46.85\%) akan tetapi dalam pemilu legislatif Joko Widodo-Juduf Kalla hanaya mendapatkan 36,46\% suara di dewan Perwakilan Rakyat. ${ }^{39}$

Berbagai pandangan telah muncul sejak dibentuknya koalisi kabinet pemerintahan pada era Susilo Bambang Yudhoyono hingga era Presiden Joko Widodo dalam kaitannya dengan sistem pemerintahan presidensial yang dianut dalam konstitusi Negara Republik Indonesia. ${ }^{40} \mathrm{Hal}$ ini disebabkan perubahan peta koalisi partai yang sebelumnya menjadi oposisi pada perkembanganya kemudian bergabung dengan pemerintahan setelah usainya pemilihan Presiden dan Wakil Presiden. Setelah memenangi pemilihan umu 2004 Presiden Susilo Bambang Yudhoyono membentuk Kabinet Indonesia Bersatu, koalisi membesar dengan melibatkan Partai Golkar, Partai Amanat Nasional (PAN), Partai Persatuan Pembangunan (PPP), Partai Kebangkitan Bangsa (PKB), Partai Bintang Reformasi (PBR), dan Partai Pelopor. ${ }^{41}$ Keberhasilan Jusuf Kalla merebut kursi Ketua Umum Golkar di awal 2005, memperkuat koalisi ini membentuk Kabinet Indonesia Bersatu, koalisi membesar dengan melibatkan Partai Golkar, Partai Amanat Nasional (PAN), Partai Persatuan Pembangunan (PPP), Partai Kebangkitan Bangsa (PKB), Partai Bintang Reformasi (PBR), dan Partai Pelopor. Keberhasilan Jusuf Kalla merebut kursi Ketua Umum Golkar di awal 2005, memperkuat koalisi ini. Pemerintah pun punya dukungan yang besar dan kuat dalam lembaga legislatif. Kesepuluh partai yang terwakili dalam Kabinet menguasai 420 $(76,4 \%)$ kursi DPR. Sementara Partai Demokrasi Indonesia-Perjuangan (PDI-P) dan lima partai kecil lain, yang berada di luar pemerintahan, hanya menguasai $130(23,6 \%)$ kursi DPR.

Koalisi terbentuk sejauh ini tidak bersifat tidak permanen bahkan cenderung berdampak disharmonisasi atau ketidakselarasan hubungan antara eksekutif dengan legislatif. Bahkan terjadi partai politik yang mendukung pemerintahan tidak selalu mendukung kebijakan kebijkan atau undang undang yang dirancanag pemerintah. Contoh persoalan yang terjadi pada Presiden Susilo Bambang YudhoyonoJusuf Kalla

37 Beverly Evangelista, "Coalition Existence in Presidential System in Indonesia According to the Constitution of Republic of Indonesia 1945," Jurnal IUS Kajian Hukum dan Keadilan 2, no. 2 (2014): 17.

38 Haris, S. Konflik presiden-DPR dan dilema transisi demokrasi di Indonesia (Grafiti, 2007), 69.

39 Romli, Lili. Op. Cit., 2.

40 Ufen, Andreas. Op.Cit., 6.

41 Kholis, Nur. Op.Cit. 11. 
yaitu keretakan koalisi terkait kasus bailout Bank Century, yang melibatkan kalangan anggota Dewan Perwakilan Rakyat Fraksi Partai Golongan Karya dalam hak angket Bank Century.Golkar proaktif agar kasus Bank Century diungkap tuntas. Demikian halnya kubu PKS dan PAN. Ketua umum partai Golkar Aburizal Bakrie memerintahkan anggotanya di DPR yang ikut dalam Pansus Hak Angket Bank Century untuk segera mengusut tun- tas dalam mendapatkan penyelesaian yang kongrit dan transparan. Ini menunjukkan bahwa, koalisi yang dibangun SBY dan partai Demokrat dengan partai-partai anggota koalisi retak dan mengalami disharmonisasi. ${ }^{42}$

Langkah yang dilakukan kedua Presiden tersebut dalam sistem Presidensial saat ini adalah bentuk dari usaha mendapatakan dukungan mayoritas di Dewan Perwakilan Rakyat dari para anggota koalaisi yang baru masuk untuk mendapat dukungan mayoritas guna mendukung kebijakan-kebijakan yang akan diambil oleh pemerintah. ${ }^{33}$ Bila mencermati koalisi yang terbentuk pada era reformasi cenderung bersifat office seeking atau didorong oleh hasrat untuk mendapatkan kekuasaan baik di eksekutif ataupun legislatif, bukan berdasarkan kesamaan program atau platform dari masing masing partai politik dalam membangun koalisi. Hal itu terlihat nyata secara kasat mata bahwa partai yang bergabung dengan koalisi pemerintah bertujuan untuk mencari posisi jabatan ataupun menteri kabinet dalam pemerintahan, dengan kata lain koalisi partai politik yang terbentuk pada era reformasi cenderung instan karena lebih berdasarkan kepentingan politik jangka pendek dan belum berdasarkan kesamaan program politik.

Kehendak konstitusi agar koalisi atau gabungan partai politik yang terbentuk pada pemilihan umum berjangka panjang dan stabil juga diperkuat oleh Mahkamah Konstitusi. Dalam Putusan Mahkamah Konstitusi terhadap perkara Nomor 14/PUUXI/2013, Mahkamah Konstitusi menyebutkan bahwa desain Undang-Undang Dasar Negara Republik Indonesia 1945 menghendaki sistem pemilihan presiden harus mendukung penguatan sistem pemerintahan presidensil, oleh karena itu koalisi yang tercipta dalam pemilihan presiden seharusnya stabil dan berjangka panjang. Kondisi yang terjadi saat ini dalam praktek menurut Mahkamah Konstitusi belum seperti yang dikehendaki konstitusi. Dalam pertimbangan hukumnya di putusan tersebut Mahkamah Konstitusi.

Dalam praktiknya koalisi yang cenderung rapuh dan diwarnai konflik internal adalah harga politik yang harus dibayar oleh Presiden Yudhoyono yang terlanjur membentuk koalisi yang semu dan mudah rapuh serta tanpa kesamaan ideologis di satu pihak. Ironisnya, keterlanjuran dan kesalahan membentuk koalisi yang dilakukan Presiden Yudhoyono pada 2004 terus berlanjut pada era Presiden Joko Widodo Jusuf Kalla pada 2014.44 Penggalanagan koalisi yang dilakukan yang ditengarai sebagai upaya untuk menguatkan sisitem Presidensial, dimana Presiden dan menteri kabinet bisa mengambil keputusan politik tanpa harus bernegosiasi panjanag dengan parlemen, kenyataannya itu tidak terlaksana dengan baik. Fakta tetap menunjukkan koalisi yang dibangun memang besar dan menghimpun banyak kekuatan politik. Namun, kebesaran koalisi ini tidak berjalan sebagaimana mestinya, karena terjadi pasang surut hubungan di kalangan partai koalisi dan isu resaffle atau pergantian kursi menteri digunakan sebagai alat untuk mengancam anggota koalisi manakala

42 Haris, S. Op.Cit. 70.

43 Ramadhan, Muhammad Febry. Op.Cit., 11.

44 Hamudy, Moh Ilham A., dan M. Saidi Rifki. Op.Cit., 14. 
terjadi anggota koalisi membelot terhadap kesepakatan koalisi. Hal ini tentu akan menghambat efektifitas Chack And Balances dalam penyelenggaraan pemerintahan.

\section{Kesimpulan}

Penerapan sistem presidensial dengan sistem multi partai akan menimbulkan tidak adanya partai politik yang memperoleh suara mayoritas dalam pemilihan umum. Partai politik perlu membentuk koalisi seperti amanat Undang Undang Nomor 42 Tahun 2008 Tentang Pemilihan Presiden dan Wakil Presiden dan Presiden terpilih harus membentuk koalisi guna menjalakan pemerintahan yang stabil. Akan tetapi koalisi yang tidak permanen dan tidak membuat menteri bertanggung jawab pada parlemen yang mengakibatkan partai politik dalam parlemen tidak mempunyai kewajiban untuk mendukung pemerintah, meskipun memiliki wakil di kabinet. Kondisi ini dalam hal hubungan antara Presiden dan DPR mempunyai kemungkinan besar terjadinya deadlock. Terjadinya deadlock berakibat pada krisis politik, krisis politik dalam sistem presidensial sangat rumit, karena Presiden tidak dapat dijatuhkan, akan tetapi Presiden sangat membutuhkan DPR untuk menjalankan programnya.

Praktik koalisi memang dilegalkan sebagaimana penjelasan pasal 6A ayat (2) UUD 1945. Pembentukan koalisi dalam sistem presidensial yang bersamaan diterapkan dengan multi partai akan mempengaruhi stabilitas pemerintahan karena pemerintahan perlu membentuk koalisi guna menjalankan program pemerintah. Koalisi yang dibangun dalam sistem presidensial tidak permanen dan tidak terinstitusionalisasi membuat koalisi rapuh dan sering terjadi konflik internal karena tidak adanya kesamaan platform diantara anggota koalisi. Koalisi semacam ini tidak dapat membuat pemerintahan yang stabil dikarenakan anggota koalisi tidak selalu mendukung kebijakan pemerintah baik legislasi maupun non legislasi.

Adapun saran yang diberikan dalam penelitian ini yaitu UUD 1945 hasil perubahan yang menguatkan sistem pemerintahan presidensial murni perlu diamandemen lagi untuk menciptakan sistem pemerintahan yang mengakomodir sistem kepartaian multipartai. Amandemen ini berkaitan dengan kedudukan dan kewenangan serta hubungan kerja antar lembaga negara untuk menciptakan sistem pemerintahan yang kuat, efektif, dan efisien serta sesuai dengan realitas masyarakat Indonesia. Sistem kepartaian multipartai merupakan keharusan bagi negara pluralis seperti Indonesia, akan tetapi partai politik peserta pemilu yang berjumlah puluhan akan mempersulit terbentuknya pemerintahan yang kuat, efektif, dan efisien. Jumlah partai politik perlu dibatasi melalui pengaturan peraturan perundang- undangan dengan memperketat seleksi partai politik peserta pemilihan umum dan memperberat persyaratan pembentukan partai politik.

\section{DAFTAR PUSTAKA}

\section{Buku:}

AR, Hanta Yuda. Presidensialisme Setengah Hati. Gramedia Pustaka Utama, 2013.

Haris, Syamsuddin. Konflik presiden-DPR dan dilema transisi demokrasi di Indonesia. Grafiti, 2007.

Manan, Bagir. Dpr, Dpd, Dan Mpr Dalam Uud 1945 Baru. FH-Uii Press, 2003. 


\section{Jurnal:}

Arman, Zuhdi. “Tinjauan Terhadap Sistem Multi Partai Dalam Sistem Pemerintahan Presidensial Di Indonesia Pada Era Reformasi." Jurnal Cahaya Keadilan 6, no. 1 (2018): 23-40.

Busroh, Firman Freaddy. "Reformulasi Penerapan Electoral Threshold dalam Sistem Kepartaian di Indonesia." Jamal Lex Librum 3, no. 2 (2017): 513-524.

Cheibub, José Antonio, Adam Przeworski, dan Sebastian M. Saiegh. "Government coalitions and legislative success under presidentialism and parliamentarism." british Journal of political science 34, no. 4 (2004): 565-587.

Dewantara, I. Gede DE Adi Atma, dan Dewa Gde Rudy. "Implikasi Hukum Koalisi Partai Politik dalam Membentuk Pemerintahan yang Efektif." Kertha Negara: Journal Ilmu Hukum, t.t.

Evangelista, Beverly. "Coalition Existence in Presidential System in Indonesia According to the Constitution of Republic of Indonesia 1945." Jurnal IUS Kajian Hukum dan Keadilan 2, no. 2 (2014).

Firdaus, Sunny Ummul. "Relevansi parliamentary threshold terhadap pelaksanaan pemilu yang demokratis." Jurnal Konstitusi 8, no. 2 (2016): 91-112.

Fossati, Diego. "Electoral reform and partisan dealignment in Indonesia." International Political Science Review 41, no. 3 (2020): 349-364.

Ginting, Fuad Putra Perdana, dan Anwar Saragih. "Ilusi Demokrasi Substansial di Indonesia: Sebuah Kritik Terhadap Impementasi Parliamentary Treshlod." Politeia: Jurnal Ilmu Politik 10, no. 2 (2018): 79-90.

Hamudy, Moh Ilham A., dan M. Saidi Rifki. "Strengthening the Multi-Party Presidential Government in Indonesia." Politik Indonesia: Indonesian Political Science Review 4, no. 2 (2019): 208-232.

Heidhues, Mary Somers. "Violent, political, and administrative repression of the Chinese minority in Indonesia, 1945-1998." Wacana 18, no. 1 (2017): 94-105.

Indra, Mexsasai. “Gagasan Penyederhanaan Jumlah Partai Politik Dihubungkan Dengan Sistem Pemerintahan Republik Indonesia." Jurnal Ilmu Hukum 1, no. 2 (2011).

Isra, Saldi. "Pemilihan Presiden Langsung dan Problematik Koalisi Dalam Sistem Presidensial." Jurnal Konstitusi, 2009, 107-131.

Kholis, Nur. "Parliamentary Threshold and Political Rights Limitation." Journal of Law and Legal Reform 1, no. 3 (2020): 445-456.

Lee, Sungdeuk, dan Burhan Djabir Magenda. "Comparative Case Study on Institutionalization of Ruling Parties Under Military Authoritarianism: Democratic Republican Party Under Park Chung-Hee Regime in South Korea (1961-1979) and GOLKAR Under Suharto Regime in Indonesia (1966-1998)." Journal of Social and Political Sciences 2, no. 4 (2019).

Lewis, Blane D. "Endogenous district magnitude and political party fragmentation in subnational Indonesia: A research note." Electoral Studies 55 (2018): 136-145.

Lowry, Robert. Indonesia: From Suharto to Democracy? Canberra, ACT: Dept. of Political and Social Change, Research School of ..., 2017. 
Marta, Auradian, Utang Suwaryo, Affan Sulaeman, dan Leo Agustino. "The Crisis of Democratic Governance in Contemporary Indonesia." Jurnal Ilmiah Peuradeun 8, no. 1 (2020): 109-128.

Naharuddin, Andi. "ELECTIONS IN INDONESIA AFTER THE FALL OF SOEHARTO," 2016.

Nurjaman, Asep. "The End of Political Party in Indonesia: The Case of Weakening Voter's Loyality in the Local Level, Malang." The Social Sciences 12, no. 2 (2017): 342-346.

Prasetya, Imam Yudhi. "Pergeseran Peran Ideologi Dalam Partai Politik." Jurnal Ilmu Politik dan Ilmu Pemerintahan 1, no. 1 (2011): 30-40.

Ramadhan, Muhammad Febry. "Politik Hukum Penyederhanaan Sistem Kepartaian Di Indonesia." Lex Renaissance 3, no. 1 (2018): 6.

Romli, Lili. "Koalisi dan Konflik Internal Partai Politik pada Era Reformasi." Jurnal Politica Dinamika Masalah Politik Dalam Negeri dan Hubungan Internasional 8, no. 2 (2018).

Savirani, Amalinda. "The Political Middle Class in Post-Soeharto Era Indonesia." Continuity and Change after Indonesia's Reforms: Contributions to an Ongoing Assessment, 2019, 128 .

Siahaan, Nico Handani. "Formula Penyederhanaan Jumlah Partai Politik Di Parlemen Pada Pemilihan Umum Indonesia." Politika: Jurnal Ilmu Politik 7, no. 1 (2016): 102-114.

Sunandar, Hendra. “Analisis sistem presidensialisme-multipartai di Indonesia: studi atas divided government dalam relasi eksekutif-legislatif pemerintahan Joko Widodo-Jusuf Kalla," 2015.

Surbakti, Ramlan, dan Kris Nugroho. “Studi Tentang Desain Kelembagaan Pemilu yang Efektif," 2015.

Ufen, Andreas. "Party presidentialization in post-Suharto Indonesia." Contemporary Politics 24, no. 3 (2018): 306-324.

Warburton, Eve, dan Edward Aspinall. "Explaining Indonesia's Democratic Regression." Contemporary Southeast Asia 41, no. 2 (2019): 255-285.

\section{Peraturan perundang-undangan:}

Undang-Undang Negara Republik Indonesia Tahun 1945 